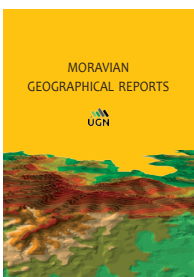

\title{
The contribution of spatial interaction modelling to spatial history: The case of central places and their hinterlands in the territory of the Austro-Hungarian Empire
}

\author{
Pavel KLAPKA ${ }^{\text {a* }}$, Martin ERLEBACH ${ }^{\text {a }}$
}

\begin{abstract}
Research on spatial history can be enriched by using approaches from quantitative geography. We analyse an historical regional system and highlight three basic assumptions, building upon Christaller's central place theory: cities do not stand alone in space, they interact with their hinterlands, and they are hierarchically organised. We investigate the relative position of central places in space and define their hinterlands using a spatial interaction modelling approach. We present the example of functional regional taxonomy in past environments, which therefore has a higher degree of uncertainty in the results and in their interpretation. We use a variant of Reilly's model to define the functional regions in Austria-Hungary at the beginning and at the end of the $20^{\text {th }}$ century. We present a possible interpretation of the model results based on the identification of the major factors responsible for developments in the urban and regional systems of AustriaHungary over 100 years. We conclude that the development of urban and regional systems in the territory of the former Austria-Hungary was not considerably affected by the role of political-economic systems, the administrative organisation of states, nor by the different stages in economic development of its formerly constituent territories.
\end{abstract}

Keywords: spatial interaction modelling, spatial history, central place theory, functional regional taxonomy, Austria-Hungary

Article history: Received 29 April 2021, Accepted 15 November 2021, Published 31 December 2021

\section{Introduction}

Research in spatial history includes a variety of issues, approaches, techniques and debates (Baker, 2003; Campbell, 2018; Ethington, 2007; Gregory and Geddes, 2014; Gregory et al., 2018; Jackle, 1971; Kingston, 2010; Rankin, 2020). Most authors agree that spatial history is at the intersection of history and geography, and that it highlights the role of geographic (recently, computerbased) information processing and visualisation. It is used to investigate the historical construction of space and relationships in space, in order to reveal new and more diverse meanings of historical events.

History per se and most of its research questions and problems cannot be separated from their spatial contexts, just as geography cannot be separated from its temporal context. In this paper, we address in general terms: (i) the past organisation of space in an historical study of urban and regional systems; (ii) the evolution of space over time; and (iii) the use of a specific methodology to accomplish our aim. The method of spatial interaction modelling, widely applied in the field of quantitative geography, enables us, apart from other things, to visualise the results in the form of a map. Spatial representations and temporal transformations of historical urban and regional systems may reveal further ways to interpret historical events and to complement standard forms of historical enquiry. Thus, the study of spatial issues can provide historians with a different view of the history of territories in general and enrich their perspectives on historical events.

In this paper we are concerned with cities and towns in a spatial and temporal context and with their roles in the organisation of space. To specify our general aim, we analyse central places and hinterlands which were part of the former Austro-Hungarian Empire. In fact, this is a study a Department of Geography, Faculty of Science, Palacký University Olomouc, Olomouc, Czech Republic
(*corresponding author: P. Klapka, e-mail: pavel.klapka@upol.cz) 
of functional regional taxonomy in the past environment. The analysis reveals the changes in the urban and regional systems of this territory through the $20^{\text {th }}$ century, a period which saw rapid development in virtually every aspect of human life, and the organisation of space was no exception. The territory of (the former) Austria-Hungary is interesting in two primary aspects. First, it perfectly represents the relatively unstable and varied space and the turbulent history of what is widely accepted as Central Europe the territory in between the large traditionally western European nation states and Russia. In this respect, AustriaHungary can be seen as a conglomerate of various cultures, nationalities, and religions, all with quite different levels of economic development, social achievement and historically conditioned organisations of urban and regional systems. The Habsburg monarchy had managed to integrate and unite, relatively successfully, these varied states for almost 400 hundred years until its collapse at the end of World War I (Beller, 2018; Evans, 2004, 2020; Judson, 2016; Kann, 1974; Rumpler and Urbanitsch, 2010; Sked, 2013; Taylor, 1976). Second, no matter which paths of socioeconomic and political development were taken by the successor states of the former Austro-Hungarian Empire, and regardless of the events and crises that have occurred over the last one hundred or more years, there are issues concerning the legacy of the Habsburg Monarchy, both in a positive and a negative sense (Abdelal, 2002; Cole, 2018; Judson, 2016, 2017; Kożuchowski, 2013; Miller and Moleron, 2018; Moos, 2016; Wheatly, 2019). Thus, overall, the territory of the former Austria-Hungary has remained a sensitive and diverse part of Europe up to now, even though its considerable area is now part of the European Union.

The remainder of the paper is organised as follows: The next section provides a reader with a basic theoretical background and explanation of our effort. The next section contains a general discussion concerning the issue of spatial interaction modelling and its uses, particularly in relation to tasks like ours. It is purposely conceived as a very concise introduction to the issue of spatial interaction modelling for non-geographers, and historians, in the form of the history of the approach. The methodological section specifies the data and the model used in this paper in the context of the territory and the time we are interested in. The penultimate section presents the results and illustrates how they can be assessed and interpreted. The concluding section returns to the question of the use of spatial interaction modelling in historical geographical problems, and some of the methodological advantages and limits of the specific model applied in our study are also outlined.

\section{Theoretical background}

While urban history is an extensive field of study in historiography (Buisseret, 1998; Ewen, 2016; Kenny and Madgin, 2015; Klautke, 2010; Rodger, 1992), it is mostly concerned with the history and development of cities and towns, including their spatial patterns and aspects (e.g. Rae, 2003). In terms of the contribution of quantitative geography to the field of spatial history, however, we emphasise three points not to be overlooked in this respect:

i. Each city does not stand alone - it is part of an urban system;

ii. Each city interacts not only with other cities, but also with its surroundings - cities serve as cores for regional systems; and iii. Each city has a different absolute and relative importance in space - there is a hierarchy of cities.

These points are partially acknowledged for instance in the historiographical work of Careless (1979) on pre-1914 Canada, of Bácskai et al. (1980) on 1828 Hungary, of Cronon (1991), concerned with the mutual relationship between Chicago and the Great West region, of Lee (2005), who studied different hinterlands of the port-city of Bremen, of Krausmann (2013), who analysed Vienna's hinterland from the energy consumption point of view, and of Bernhardt (2019), who discussed the transformation of the urban hinterland of Berlin. More general views of cities and their surroundings are presented by Mohl (1998), Fields (1999), and Barles and Knoll (2019).

All three points, mutually constitutive, made in the preceding paragraph are, to a large extent, included in Christaller's Central Place Theory (Christaller, 1933). In brief, according to this theory, settlements (i.e. cities and towns) are so-called central places which provide services to their respective surrounding areas, their hinterlands. Actually, this is also the case of so-called functional regions (for details: see Klapka and Halás, 2016). Central places are hierarchically organised according to their size and functions, and the spatial extent of their hinterlands reflects the sizes of central places. Going beyond this traditional theory, we point out that while the 'absolute' importance of a central place can be easily expressed by its population, its 'relative' importance can provide us with much more information on the organisation of urban and regional systems. In order to assess the 'relative' position of central places and their role in space, we need information on the functional relationships in space that are at our disposal. The functional relationships between central places and between a central place and its hinterland are usually assessed through the analysis of spatial interactions (i.e. quantifiable movements of people, goods, etc.). In quantitative geography, spatial interactions are understood as vector data, with their origins and destinations in space (see e.g. Klapka and Halás, 2016).

This type of vector information has rarely or never been available concerning past environments and situations. Fortunately, geography has at its disposal a set of techniques that could be used for the objectives of the current paper: spatial interaction modelling (see next section). We consider whether and how spatial interaction modelling can provide us with some special insights into, and knowledge of, past geographical environments and their development, particularly with regard to the organisation of space. Thus, we present and highlight the possibility of employing a spatial interaction model which assesses the relative importance of central places within an urban system, and which defines the hinterlands of central places in order to construct a regional system. This approach also enables us to compare spatial patterns from different periods and to capture their evolution over time.

\section{Spatial interaction modelling}

Spatial interaction modelling has quite a long and rich tradition in the quantitative avenues of geographical research, and it can be used for many purposes of very different character (see for example: Clarke and Birkin, 2018; Fotheringham et al., 2000; Fotheringham and O'Kelly, 1989; Roy and Thill, 2004; Sen and Smith, 1995; Wilson, 2010). Spatial interaction modelling and central places are explicitly discussed by Batty, 1978, Fik and Mulligan, 1990, and 
Openshaw and Veneris, 2003. In general, the most frequent applications attempt to explain and predict current and future spatial interactions (Fotheringham and O'Kelly, 1989), when 'real' (i.e. statistical) information on movements and contacts among places is not available for any reason (such as it is not recorded at all, or it does not cover the whole territory under consideration) and when the quality of the information is insufficient. This facet of such research can be related easily to the focus of this paper as defined in the introduction, when the analysis of past urban and regional systems is burdened with the lack of statistical information on spatial interactions. ${ }^{1}$ Spatial interaction modelling is also a suitable tool for assessing the historical development of phenomena where real information is available only for some points in time.

\subsection{Foundations}

Spatial interactions are a consequence of the polarity of the Earth's surface and its distinct heterogeneity. Horizontal spatial interactions (also movements, flows, contacts), as the phenomena balancing the polarity, can be conditioned environmentally (atmospheric circulation, slope processes, etc.) based on natural laws, and socio-economically based on aggregated human behaviours in time-space. It is the latter case that encouraged extensive research into spatial interactions and their modelling in Human Geography. Behaviourally conditioned spatial interactions include various aggregations of individual, personal, material, product, financial and information movements, and contacts. Spatial interactions occur at various scales between various sections of the Earth's surface and a range of places (localities).

Several theoretical frameworks for spatial interaction modelling have been developed since its beginnings in the $19^{\text {th }}$ century (Fotheringham et al., 2000). The first attempts built on simple Newtonian physical analogies (Carey, 1858; Ravenstein, 1885), which were later called demographic gravitation (Stewart, 1948). Human interaction behaviour was thought to follow the analogy of physical laws (hence also the term 'social physics') expressed for instance in the principle of the least effort (Zipf, 1949). Since the end of the 1960s, other physical analogies, based on the second law of thermodynamics (Wilson, 1967, 1970, 1974), the theory of movement (Alonso, 1978) and information theory (Plane, 1982; Snickars and Weibull, 1977), have formed the theoretical background for spatial interaction modelling. Wilson's approach using entropy maximisation, employing probability, and defining a so-called family of spatial interaction models (Wilson, 1971), is still one of the most important conceptual bases for spatial interaction modelling. More recent overviews include those by Wilson, 2010, 2018; Fotheringham and O'Kelly, 1989; Gordon, 2010; Pooler, 1994; Roy and Thill, 2004; Senior, 1979; Sheppard, 1978. Later criticism arose during the $1980 \mathrm{~s}$ and pointed to the physicalist basis of the models, which was deemed to have no support in relation to the real behaviour of individuals. Therefore, new behaviourally conditioned concepts evolved based for instance on spatial information processing, spatial choice, and spatial decisions (Fotheringham, 1983, 1986; Hu and Pooler, 2002). These behavioural probabilistic models require difficult-to-gain information on how individuals make their decisions, and this is usually tackled by the employment of hierarchical choice and by finding suitable attributes of destinations (Fotheringham et al., 2000).

\subsection{Modelling hinterlands}

Spatial interaction models can be used and adjusted to analyse movements and contacts in three main ways: (i) as flows along lines; (ii) as the accessibility of points; and (iii) as hinterlands of places. All models require knowledge of the size of places (also masses) and the distances between them. It is assumed that spatial interactions increase with size and decrease with distance. The crucial question is how the interaction decreases with distance, and several socalled distance-decay functions are applied to express this decrease (see for example: Fotheringham, 1981; Halás and Klapka, 2015; Sheppard, 1978; Wilson, 1974). Each model includes one or several parameters which calibrate the model to produce reasonable results. This is the basic principle, and it is applied and developed in many and varied ways, based on the research task, information quality, geographical context, distance-decay function used, etc.

The current paper pursues the third form of analysis mentioned above, and its development will be detailed further. The first attempts to define the hinterlands of places are related to the work of William J. Reilly $(1929,1931)$. He proposed the law of retail gravitation based on empirical observations of 'retail trade influence', originally carried out in Texas, where retailers and housewives were interviewed. He noticed that the attraction forces of two centres in the intermediate place are approximately directly proportional to the population of centres and inversely proportional to the squared distance between the centres and the intermediate place. Square distance is in fact the value for the model parameter equal to 2 (see below). He introduced the notion of the breaking point, where the influence of both centres is equal.

Converse (1949) expressed mathematically, and determined precisely, the location of the breaking point between two shopping centres. He also tested his assumptions through a consumer survey and paid careful attention to the value of the model parameter - cubic distance instead of square distance. Huff $(1963,1964)$ discusses how to delineate intra-urban retail trade areas and considers all competing centres in a system. He observes that the breaking point does not mean a sharp boundary between two facilities. Rather, it shows where the influence of one centre fades and the other starts to prevail. As for the model parameter, Huff suggests that it varies between 1.5 and 3 based on the type of movement and the geographic context. He points out that the variety of goods and the travel time can be employed to express the probability of a customer making a shopping trip. This probability can be graphically expressed by isopleths. Thompson (1966) assesses the early variants of retail area models and suggests their application in other research directions. The validity of the law of retail gravitation was challenged for instance by Jung (1959) and Berry (1967).

Wilson (1970), who defined a family of interaction models based on the principle of entropy maximising, showed that the law of retail gravitation was in fact a special

\footnotetext{
1 There are, however, some rare exceptions when there is a statistical record of past movements for some territory, such as migration in southern Sweden (Hägerstrand, 1957). In the territory of Austria-Hungary, Bálint (2016) attempts to capture historical migration between Austrian and Hungary. Deméter and Bagdi (2018) present several approaches to reveal real migration patterns in Hungary. These latter works represent a macro-view of the migration patterns, however.
} 
case of the unconstrained gravity model; this put the law of retail gravitation within a theoretically well-defined general scheme of spatial interaction models. The original formulation of the law of retail gravitation was critically discussed by Batty (1978), who also suggests its mathematical reformulation based on contemporary knowledge and in the context of Central Place Theory. After 1980, the original Reilly model and its extensions have been only marginally used and developed. Ianos (1987) applied the model in the regionalisation of Romania. Parr (1997) compared the law of retail gravitation to the law of market areas and found a number of common characteristics. Lee and Pace (2005) modelled the spatial distribution of retail sales between shopping malls. Řehák et al. (2009) and Halás and Klapka (2010, 2012) modified Reilly's original model, proposed its three variants (geometric, topographic, oscillatory) and applied them to the territories of the Czech Republic and Slovakia.

\subsection{Spatial interaction modelling in historical and archaeological research}

The current use of spatial interaction modelling in historical and archaeological research is exceptional, which is particularly true when speaking of the Modern Age as approximately to the end of the $19^{\text {th }}$ century. Doorn (1985) applied a simple gravity model to early modern-day Greece. Rihll and Wilson (1987) were concerned with Ancient Greece and the grouping of settlements into regions based on the entropy-maximising gravity model. A similar task was dealt with by Klapka and Niedźwiedźová (2010), who used Reilly's model to define the hinterland of a smaller industrial centre in the present-day Czech Republic during the Industrial Revolution, and used a simple gravity formula to analyse its inner structure. Rehák et al. (2009) used Reilly's model to compare, besides others, the hinterlands of Czech central places in 1900 and 2001. They acknowledged the role of spatial interaction modelling in the analysis of the past spatial organisation of territories. Wilson (2012) returned to the study of Ancient Greece and analysed the development of the urban system in the USA in the context of railway development. More attention was paid to ancient history and archaeology. Bevan and Wilson (2013) modelled settlement hierarchies in Bronze Age Crete. Davies et al. (2014), Altaweel (2015) and Altaweel et al. (2015) analysed settlement structure, change and hierarchy in various parts of present-day Iraq and Syria during the Bronze and Iron Age. Filet (2017) modelled Latenian cultural trade interactions in nonMediterranean Europe using the same model as Rihll and Wilson (1987). Györi (2000) modelled trade gravitation areas in the Little Hungarian Plain for the year of 1925. Demeter and Radics (2009) used the gravity principle and Central Place Theory to examine cores and peripheries after the demise of Austria-Hungary. Györi and Jankó (2009) defined gravity-based hinterlands in Burgenland and Western Hungary for 1910 and 2001. Szilágyi (2017) used a gravity potential model to visualise areas lacking cites in the Great Hungarian Plain.

\section{Data and model specification}

Concise, sufficient, and clear mathematical derivations and formulations of general spatial interaction models are given for instance by Rihll and Wilson (1987) and Wilson (2010). In this paper, we use an adjusted and improved Reilly's model, which is detailed below. From three versions defined by Řehák et al. (2009), the geometric variant was chosen for our purpose; the topographic variant uses real distances along transport networks and is determined to assign basic spatial units (such as municipalities) to competing central places; a similarly constructed oscillatory variant is designed to identify the overlapping hinterlands of central places. Although we will return to the assessment of the geometric variant in the concluding section, some of its properties are now due to be presented about our specific research task.

Apart from the distances between central places, the model requires us to express their sizes (masses), which can also be seen as their centrality functions. The specification of size needs to reflect the research task, data availability and comparability. In this paper we use the population of central places to express their centrality function. The population is suitable for general definitions of hinterlands. It is simple but also the most universal and comparable expression of size, and information concerning population is readily available for central places in the past. Other expressions can be distorted by the functional specialisations of some central places.

We took the populations of central places from the 1900 census, ${ }^{2}$ carried out by the Austro-Hungarian Empire, and the later censuses from most of its successor states over 100 years later. These were carried out in 2001 in Austria, Croatia, the Czech Republic, Hungary, Italy, Slovakia, and the Ukraine; in 2002 in Poland, Romania, Serbia (i.e. Yugoslavia) and Slovenia. ${ }^{3}$ Numbers for Bosnia and Hercegovina were acquired from Internet estimates from 2002. ${ }^{4}$ The population of Gorizia is the sum of numbers in the Italian (for Gorizia) and the Slovenian censuses (for Nova Gorica). Cities with more than 100,000 inhabitants at the beginning of the $21^{\text {st }}$ century, and the capitals of the internal division units of Austria-Hungary which were smaller than 100,000 , were taken as the central places. The latter category only included the cities of Bolzano, Klagenfurt and Opava in Cisleithania. Where possible the populations of central places were related to the administrative boundaries of cities from the beginning of the $21^{\text {st }}$ century so that spatial comparability is secured.

The original Reilly's law is mathematically formulated as:

$$
\left(p_{k i} / p_{k j}\right)=\left(M_{i} / M_{j}\right)^{\alpha} \times\left(d_{k i} / d_{k j}\right)^{\beta},
$$

where $p_{k i}$ and $p_{k j}$ are the probabilities of expected shopping travel from a place $k$ to central places $i$ and $j, M_{i}$ and $M_{j}$ are the sizes of central places $i$ and $j$ (usually $M_{i} \geq M_{j}$ ), $d_{k i}$ and $d_{k j}$ are the distance from a place $k$ to central places $i$ and $j, \alpha$ and $\beta$ are the parameters to be estimated ( $\alpha$ is assumed to be unity). Now we can proceed further to the identification of the breaking point between the spatial influences of central places $i$ and $j$. This is based on the assumption that

\footnotetext{
${ }^{2}$ K. K. Statistischen Zentralkommission ed. (1903-1908): Gemeindelexikon der im Reichsrate vertretenen Königsreiche und Länder I-XIV. Hölder, Vienna. Kön Ungarischen Statistischen Zentralamt ed. (1902): Volkszählung in der Länder der Ungarischen Krone vom Jahre 1900, erster Teil. Pester Buchdruckerei, Budapest. Numbers for Bosnia and Herzegovina are retrieved from the 1895 census - Zemaljska vlada za Bosnu i Hercegovinu ed. (1896): Glavni rezultati popisa žiteljstva u Bosni i Hercegovini od 22. aprila 1895 sa podacima o teritorijalnom razdjeljenju, javnim zavodima i rudnim vrelima. Sarajevo.

${ }^{3}$ Data were retrieved from respective national statistical offices.

${ }^{4}$ https://en.wikipedia.org/wiki/Demographics_of_Sarajevo; https://en.wikipedia.org/wiki/Historical_population_of_Banja_Luka
} 


$$
\left(p_{k i} / p_{k j}\right)=1
$$

Thus, if [1] is equal to unity according to [2], then

$$
\sqrt[\beta]{\frac{M_{i}}{M_{j}}}=\frac{d_{i j}-d_{k j}}{d_{k j}} .
$$

Thus

$$
d_{k j}=d_{i j} / \sqrt[\beta]{\frac{M_{i}}{M_{j}}+1},
$$

which is the distance from a smaller central place to the breaking point. Now we can derive the whole set of breaking points in the form of a circle on condition that we identify its centre. The equation [4] can also be expressed as:

$$
d_{i j}=\sqrt[\beta]{\frac{M_{i}}{M_{j}}} \times d_{k j}+d_{k j},
$$

which divides $d_{i j}$ into two parts. It enables us to construct a circle (Parr, 1997; Řehák et al., 2009) with its radius:

$$
r=d_{k j} \times \sqrt[\beta]{\frac{M_{i}}{M_{j}}} / \sqrt[\beta]{\frac{M_{i}}{M_{j}}}-1,
$$

when $r>d_{k j}$ and $r$ is plotted from the breaking point towards (and in fact always behind) a smaller central place along the axis connecting $i$ and $j$, where the centre of the circle is located. This circle circumscribes the hinterland of a smaller central place against larger central place.

In practice, the largest and the second largest central places are the first to be considered, and the territory under study is divided between their respective hinterlands. Then the third largest central place is taken and dealt with the larger place to whose hinterland it belongs. This procedure is repeated until all central places have their hinterlands defined. If a circle intersects another circle(s), then any respective pair of central places must be taken into consideration. This in fact ensures that the regional system is taken as a whole and that selected pairs of central places are not dealt with out of context. Therefore, in practice the final shape of a central place's hinterland can consist of a system of arcs related to various relevant pairs of central places and their respective hinterlands. Likewise, it means that some arcs of circles are rendered redundant and must be deleted from the graphical expression of the results.

The last issue to be addressed is that of the $\beta$ parameter value. In Newtonian physics this value equals 2 . But leaving celestial bodies aside, questions concerning the parameter value in socio-spatial research remain open. In historical tasks it can become rather complicated. This value is usually estimated during the calibration of a spatial interaction model, but in this case at least some and sufficient preliminary knowledge of the real interaction patterns is required. The calibration is basically done through the approximation of modelled interactions onto real interactions, while adjusting the parameter value. ${ }^{5}$ For the territory of AustriaHungary, we have no knowledge of sufficient, applicable and comparable real interactions (such as travel-to-work flows) until the second half of the $20^{\text {th }}$ century. Although some local studies exist (see e.g. Györi, 2000), if the model is calibrated based on these quite unique data, its performance in different parts of the Empire with various levels of socio-economic development could be seriously compromised. Moreover, the parameter value estimates can tend to be spatially nonstationary, but the discussion on non-stationarity is well out of the scope of the paper (see e.g. Fotheringham et al. (1996) for clear explanation of the concept of non-stationarity).

As an acceptable calibration of the 'historically oriented' model is almost impossible, another means of setting the parameter value must be used. In his original empirical study, Reilly (1929) found that the parameter value most frequently ranges between 1.5 and 2.5, the closest whole number being 2 . These values are also retained by Parr (1997). Converse (1949) uses $\beta=2$ and if there is a distinct difference in the sizes of towns then $\beta=3$. In this study we follow these traditional suggestions and use the parameter value $\beta=2$.

\section{Results and their interpretation}

The hinterlands of central places in the territory of the (former) Austro-Hungarian Empire defined by the model application are shown in Figure 1. The map itself requires a short commentary. For the modelled situation of 1900, the territorial units of the inner division of the Dual Monarchy are shown for easier and more comprehensible interpretation. Cisleithania (officially the Kingdoms and Lands represented in the Imperial Council) is divided into crown lands - historical political units with various former statuses. In contrast, Transleithania (officially the Lands of the Holy Hungarian Crown of St Stephen) is divided into the Kingdom of Croatia-Slavonia and Hungary proper. The latter territory consists of so-called comitatuses, which are too small to be compared to the Cisleithanian crown lands. Therefore, seven statistical regions (so-called 'circles'), consisting of these comitatuses, are shown on the map. Finally, there is the Condominium of Bosnia and Herzegovina, which was governed jointly by both parts of the Empire. One hundred years later the situation had changed completely because of several major events (both World Wars, the fall of the Iron Curtain). The boundaries of independent states are shown on the map. The territory of the former Dual Monarchy is currently under the governance of thirteen independent states (see above the section on statistical data, the thirteenth state being Monte Negro). It is symptomatic that even the administrative boundaries point to the complex histories of this part of Europe.

The main features of the initial situation and the pattern of the hinterlands in 1900 will be outlined before we proceed to the assessment of the most apparent aspects of spatial developments that occurred in the $20^{\text {th }}$ century. The distinct aspect of the organisation of space is the significant dominance of the capitals of both parts of the Dual Monarchy - Vienna and Budapest. The dominance is quite noticeable in the case of Vienna, the largest city in the Empire, whose hinterland includes substantial parts of such distant areas as Bosnia and Hercegovina and Dalmatia and, less surprisingly, parts of Moravia. The influence of Vienna reaches parts of Vorarlberg, Tyrol and Silesia and extends

\footnotetext{
${ }^{5}$ Rihhl and Wilson (1987) suggest that models can be calibrated based on the knowledge of some other aspects of spatial structures if real flows are not known, such as the importance of places.
} 


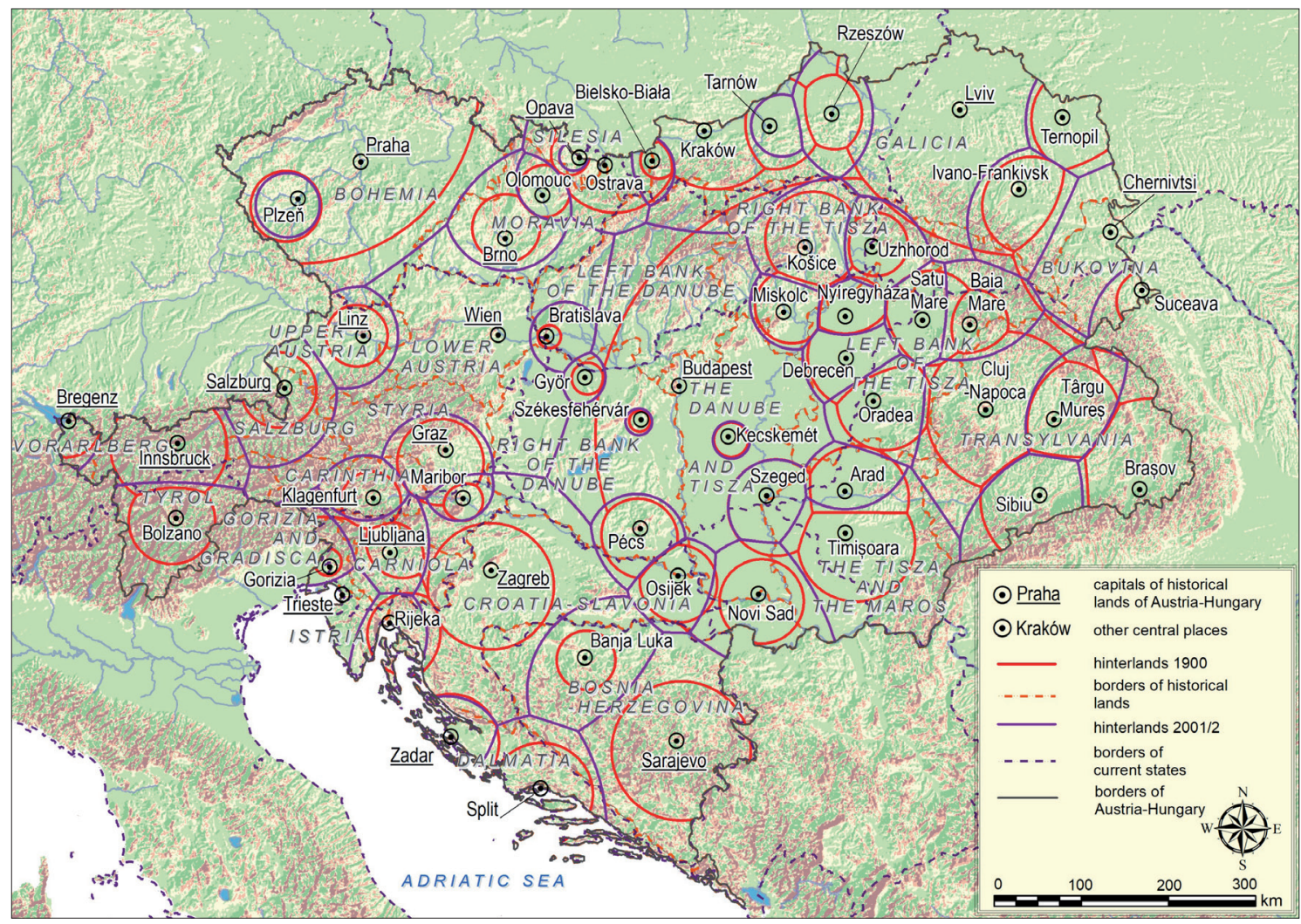

Fig. 1: Central places and their hinterlands in Austria-Hungary in 1900 and 2001 Source: Author's elaboration

along a strip dividing the western part of Galicia from northern Hungary. Seemingly illogical, the hinterland of Vienna includes the north-eastern part of Transylvania, but this is how the model deals with the largest city in the system. The dominance of both capitals, Vienna, in particular, can be documented in the hinterland of the third largest city in the Empire, Prague, which does not even include the whole territory of Bohemia. Except for Lviv (Galicia), the hinterlands of other central places are only small.

To interpret developments over time correctly, the relativizing effect of spatial interaction models needs to be considered. This means that the population of a central place itself is not as crucial as the mutual ('relativized') relations among central places in space. Distance plays the most significant role in this respect. For instance, the hinterland of Kecskemét changed very little over the hundred years, but that does not mean its population stayed the same. It means that its population changed (increased) in almost the same relative number (proportion) as did the population of Budapest, against which the hinterland of Kecskemét is defined.

The development of society during the $20^{\text {th }}$ century is reflected in the organisation of space in several respects. This can be shown through the changes that occurred in the hinterlands of central places. First, the hinterlands of both capitals of the Dual Monarchy were reduced significantly, particularly in favour of the hinterlands of 'new capitals'. There are several types of these 'new' central places: i. Federal capitals in the new multi-national states of the former Yugoslavia (Zagreb, Sarajevo, Ljubljana, Novi Sad) and Czechoslovakia (Prague ${ }^{6}$, Bratislava), formed in 1918 and dissolved shortly after 1989, virtually completing the demise of Austria-Hungary and the establishment of nation states;

ii. Federal capitals in Austria (Salzburg, Linz, Klagenfurt, Graz); and

iii. 'Capitals' based solely on cultural and economic attributes $^{7}$ (e.g. Kraków, Brno, Timişoara, Banja Luka, Split).

In the case of cities (Brno, Bratislava, Linz) located relatively near to Vienna, the relative increase in their influence was further driven by the decrease in the influence of Vienna, which was one of the steepest falls in the territory of the former Empire. Also deserving of our attention is the fact that the increase in the spatial extent of the hinterlands of the new capitals was not affected by the existence of the Iron Curtain which split the former Empire after 1945, or by the differences in economic levels. The political-economic system seems to have played a smaller role than general economic, cultural, and social development in this respect.

Second, apart from both capitals of the Dual Monarchy, there are other cases where the hinterlands of central places have shrunk. The shrinkage is most distinct in the case of Trieste, which is, together with Vienna, the only

\footnotetext{
${ }^{6}$ Prague can be seen as a special case. It is the third largest city in the system, it is by far the oldest of the 'new' capitals (1918) and it is an historical capital. This makes Prague more similar to Vienna and Budapest; also the expansion of Prague's hinterland is modest in comparison to Zagreb and Bratislava but also to Salzburg and, Innsbruck.

${ }^{7}$ Of course, culture and economy also contributed to the increased influence of the first two types of capitals, together with political and administrative reasons.
} 
central place that had less population at the end of the $20^{\text {th }}$ century than it did at the beginning. Trieste was the main commercial seaport of Austria-Hungary. The city lost its importance considerably in this respect during the $20^{\text {th }}$ century because Italy has several more suitable ports and Trieste was in the immediate vicinity of the Iron Curtain, and its political status was not resolved until 1954. The remaining cases are the cities of Lviv and Chernivtsi (former capitals of Galicia and Bukovina respectively), which lost their importance due to extreme peripherality during Soviet times, and the city of Tarnów, whose significance faded as it was in the vicinity of Kraków which, after 1918, rapidly grew in size and importance, and in part because of its own migration-related population decrease at the end of the $20^{\text {th }}$ century.

Third, stable spatial relations during the $20^{\text {th }}$ century are visible in the territories of present-day Hungary, the eastern part of Transylvania and Bohemia. Interesting situations can be found in territories with a mix of stable and unstable relations. Bohemia and Moravia (today's Czech Republic) show internal stability in the hinterlands of their central places, which, in contrast, increased their importance in relation to Vienna. Central places near the borders of today's Hungary have stable relations with Budapest but lost their importance to central places in Serbia and Romania (typical examples are Szeged and Novi Sad, Timisoara, Arad) Today's Romania shows stable relations in Transylvania (Braşov, Tărgu Mureş, Sibiu, Cluj-Napoca), while in its northwestern territory, which has a Hungarian minority, the hinterlands of such places as Timisoara, Oradea and Baia Mare have expanded. ${ }^{8}$

In most cases referred to above, the mixed situations are conditioned by the emergence of new state borders, and this can be interpreted as a source of instability for urban and regional systems as they were in the Habsburg Monarchy. Although some sections of newly established Hungarian borders, after the end of the World War I, respect physical geographical features (the Danube and Ipel'/Ipoly Rivers in the case of Czechoslovakia; the Mura and Drava/Dráva Rivers in the case of Yugoslavia), the bulk of the new borders did not respect long-lasting functional relationships in the territory (and its administration), ethnic and partly also religious composition (e.g. Demeter, 2020; Hajdú, 2020; Szilágyi and Elekes, 2020), which affected negatively particularly the Hungarian areas along the Eastern-Slovakian, Ukrainian, Romanian and Croatian border sections (cf. SüliZakar, 1992; Papp and Pénzes, 2017; Pénzes, 2020; Szilágyi and Elekes, 2020).

In contrast, the development of central places behind the Hungarian borders might be boosted based on political reasons, when for instance larger Romanian industrial cities were fed by intensive in-migration of ethnically Romanian population. ${ }^{9}$ Nevertheless, some cross-border relations remained stable during the $20^{\text {th }}$ century: Osijek-Pécs; Oradea-Debrecen; Satu Mare-Debrecen, Nyíregyháza. In contrast, the removal of borders induced the development of Polish central places. A special instance of mixed ('converging') relations can be found in today's Ukraine, where the hinterlands of larger central places (Lviv, Chernivtsi) shrank and the hinterlands of smaller central places (Ternopil, Ivano-Frankivsk, Uzhhorod) expanded. Possible reasons can be seen in Soviet policies of levelling economic differences.

At the end of the $20^{\text {th }}$ century Budapest was the largest central place in the former Austro-Hungarian Empire. Its hinterland expanded west at the expense of the hinterland of Vienna. The hinterlands of the 'new capitals' expanded considerably and more fully covered their respective territories. That is particularly so in the cases of Zagreb, Sarajevo, Ljubljana and, partly, Prague. Even Bratislava, located close to Vienna, expanded its hinterland; however, it does not yet cover a significant part of Slovakia.

\section{Conclusion}

We have presented the possible use of spatial interaction modelling in the field of spatial history and historical geographical research. We have applied a geometric variant of an adjusted and improved Reilly's model. This is a relatively easy way to define the hinterlands of central places for quite general purposes, such as the regionalisation of territories, and capturing the basic features of urban and regional systems. We have analysed the situation in AustriaHungary in the $20^{\text {th }}$ century and presented a very general illustration of the historical geographical interpretation of the model results.

The model has its advantages and limitations, which go hand in hand. The main advantage is that it offers a simple assessment of basic relations within the urban systems of territories, and this is quite easily attainable - we only need the sizes of central places and the orthodromic distances between them. Thus, it is not necessary to consider any units of inner divisions of the territories or transport networks. This would be rather problematic because the units and networks have different historical backgrounds and geographical logic in various parts of Austria-Hungary, despite the centralistic efforts in respective parts of the Dual Monarchy, and this is particularly true for the differences between Cisleithania and Transleithania. The model is quite independent about the availability of data, their quality, and their comparability, both in time and space. The model is not a mere mapping of the historical data, but it acknowledges the mutual relations and dependencies in space, which are relativized through the interaction approach.

In contrast, the model has its limitations. The relative ease of its construction is at the expense of more detailed results and a more thorough interpretation. It works with an isotropic space and ignores real features of the environment, particularly the physical geography. In some parts of the territory, however, the model can approximate physical geographical borders, for instance the mountain ranges between Innsbruck and Bolzano, Ljubljana and Klagenfurt, Rijeka and Trieste, and the orographic barrier of central Slovakia and the north-eastern Carpathians. The model also does not take into consideration the effects of any areas outside the former Austria-Hungary

The concrete application of the model on the territory of Austria-Hungary has revealed some more general aspects of the development of its urban and regional systems. Four

\footnotetext{
${ }^{8}$ An interesting interpretation of the changing roles and functions of centres along wider Hungarian-Romanian border zone is put forth by Szilágyi and Elekes (2020). Some of their findings in this respect corroborate those reported here (regarding for example: Cluj-Napoca, Timişoara, Baia Mare).

${ }^{9}$ See Kocsis and Tátrai (2021, p. 71). Szilágyi and Elekes (2020, p. 104) mention for instance Baia Mare.
} 
types of situations regarding the hinterlands of the central places have been identified: (i) stability; (ii) a trend towards expansion; (iii) a trend towards shrinkage; and (iv) mixed development. We suggest that the situations are mostly related to political (state) and administrative (intra-state) borders which are the products of major geopolitical and socio-economic changes that took place during the $20^{\text {th }}$ century. Such changes start with the dissolution of AustriaHungary, then the rise and fall of the Iron Curtain, followed by the dissolution of the Soviet Union, Yugoslavia, and Czechoslovakia.

As the result, the 'monocentric' or better still 'duocentric' urban and regional model of the Austro-Hungarian Empire has been replaced by polycentric (Bosnia and Hercegovina, Slovenia, Croatia, relevant parts of Poland, Romania, the Ukraine) or semi-polycentric (Austria, the Czech Republic) models over the whole territory of the former Empire, and within its successor states. One exception is present-day Hungary, see further, which has remained extremely monocentric) at a lower hierarchical level of the transformation process.

The prevailing tendencies we have identified are quite irrespective of:

i. The historical role of a political-economic system: it does not matter whether market economy (Austria), planned economy (Czechoslovakia, Poland, Romania, the Soviet Union) or the mixed system of Yugoslavia, which was effective in that territory for some time, prevailed;

ii. The administrative system: it does not matter whether it is a national federal state (Austria), a multi-national federation (Czechoslovakia, Yugoslavia, the Soviet Union) or a 'centralised' national (Poland) or multinational (Romania) state; and

iii. The economic level: it does not matter whether it is a traditionally developed state (Austria), a successfully transformed state (the Czech Republic) or a transforming state (Romania)

In this respect the traditions and legacy of AustriaHungary appear to be surprisingly clear. The tendencies seem to build on the trajectory set during the period of Austria-Hungary and to reflect a global or at least a EuroAtlantic socio-economic development based on the theories of regional development supporting decentralisation and deconcentration in the organisation of space. ${ }^{10}$

As mentioned earlier, the exception to the identified three prevailing tendencies is present-day Hungary. It is partly the tale of its modern state borders, which differs much from more traditional and stable boundaries (both international and intra-state) in many other parts of the former Empire. The borders of present-day Hungary were based on political and military-strategic reasons favouring, quite logically, the needs of newly established victorious states, and they were confirmed by the Treaty of Trianon. The non-existence of traditional borders brought a huge disruption of existing human geographical relationships in the Great Hungarian Plain, which has brought economic and social problems along some sections of new state borders and affected the development paths of border regions. ${ }^{11}$
We have presented the way in which the model can be interpreted, and we have put forth some basic historical causes for the changes in the organisation of space. In contrast, the spatial development of urban and regional systems can be used as a referential framework and a context for more specific historiographical studies (such as Makaš and Conley, 2009), which could hopefully enrich historiography with further knowledge of the spatial aspects.

\section{Acknowledgement}

This work was supported by the Czech Science Foundation under Grant "Spatial interactions and their conceptualisation: analysis of selectivity, uncertainty and hierarchy" No. GA20-21360S. The authors would like to express thanks to Associate Professor János Pénzes, whose help with Hungarian literature and context was invaluable.

\section{References:}

ABDELAL, R. (2002): Purpose and privation: nation and economy in post-Habsburg Eastern Europe and postSoviet Eurasia. East European Politics and Societies, 16(3): 898-933.

ALONSO, W. (1978): A theory of movement. In: Hansen, N. M. [ed.]: Human Settlement Systems: International Perspectives on Structure, Change and Public Policy (pp. 197-211). Cambridge, MA, Ballinger.

ALTAWEEL, M. (2015): Settlement dynamics and hierarchy from agent decision-making: a method derived from entropy maximization. Journal of Archaeological Method and Theory 22(4): 1122-1150.

ALTAWEEL, M., PALMISANO, A., HRITZ, C. (2015): Evaluating settlement structures in the ancient Near East using spatial interaction entropy maximization. Structure \& Dynamics: eJournal of Anthropological \& Related Sciences, 8(1) [online]. Available at: https:// escholarship.org/uc/item/4kv4p936

BÁCSKAI, V., NAGY, L., PARTI, J. (1980): Market areas, market centres and towns in Hungary in 1828. Acta Historica Academiae Scientiarum Hungaricae, 26(1/2): 1-25.

BAKER, A. (2003): Geography and history: bridging the divide (Cambridge Studies in Historical Geography). Cambridge, UK: Cambridge University Press.

BÁLINT, H. (2016): Ausztria és Magyarország migrációs kapcsolata a dualizmus idején (1870-1910) Földrajzi Közlemények, 140(4): 362-375.

BARLES, S., KNOLL, M. (2019): Long-term transitions, urban imprint and the construction of hinterlands. In: Soens, T. et al. [eds.]: Urbanizing nature: actors and agency (dis)connecting cities and nature since 1500 . Oxon, Routledge.

BATTY, M. (1978): Reilly's challenge: new laws of retail gravitation which define systems of central places. Environment and Planning A, 10(2): 185-219.

\footnotetext{
${ }^{10}$ For this extremely wide and complex issue, see for instance the basic overview in Capello and Nijkamp (2019), Stimson et al. (2006); for the transformation of settlement system and polycentricity, see Davoudi (2003), Hall and Pain (2006), Rozenblat and Pumain (2018). See also Demeter (2020) for a historian's view related to the territory of Austria-Hungary.

${ }^{11}$ Presenting the Hungarian point of view, there is a suitable historical-geographical outline in English published by Demeter (2020).
} 
BELLER, S. (2018): The Habsburg Monarchy 1815-1918. Cambridge, UK, Cambridge University Press.

BERNHARDT, C. (2019): Concepts of urban agency and the transformation of urban hinterlands: The case of Berlin, eighteenth to twentieth centuries. In: Soens, T. et al. [eds.]: Urbanizing nature: actors and agency (dis) connecting cities and nature since 1500. Oxon, Routledge.

BERRY, B. J. L. (1967): Geography of market centres and retail distribution. Englewood Cliffs, Prentice-Hall.

BEVAN, A., WILSON, A. (2013): Models of settlement hierarchy based on partial evidence. Journal of Archaeological Science, 40(5): 2415-2427.

BUISSERET, D. [ed.] (1998): Envisioning the city: six studies in urban cartography. Chicago, University of Chicago Press.

CAMPBELL, C. J. (2018): Space, place and scale: Human geography and spatial history in past and present. Past and Present, 239(1): e23-e45.

CAPELLO, R., NIJKAMP, P. [eds.] (2019): Handbook of regional growth and development theories: revised and extended second edition. Cheltenham, Edward Elgar Publishing.

CARELESS, J. M. S. (1979): Metropolis and region: the interplay between city and region in Canadian history before 1914. Urban History Review/Revue d'histoire urbaine, 7(3-78): 99-118.

CAREY, H. C. (1858): Principles of social science. Vol. 1. Philadelphia, J. B. Lippincott \& Co.

CHRISTALLER, W. (1933): Die zentralen Orte in Süddeutschland. Jena, Gustav Fischer.

CLARKE, M., BIRKIN, M. (2018): Spatial interaction models: from numerical experiments to commercial applications. Applied Spatial Analysis and Policy, 11(4): 713-729.

COLE, L. (2018): Visions and revisions of empire: reflections on a new history of the Habsburg Monarchy. Austrian History Yearbook, 49: 261-280.

CONVERSE, P. D. (1949): New laws of retail gravitation. Journal of Marketing, 14(3): 379-384.

CRONON, W. (1991): Nature's metropolis: Chicago and the Great West. New York-London, W. W. Norton \& Company.

DAVIES, T., FRY, H., WILSON, A., PALMISANO, A. ALTAWEEL, M., RADNER, K. (2014): Application of an entropy maximizing and dynamics model for understanding settlement structure: the Khabur Triangle in the Middle Bronze and Iron Ages. Journal of Archaeological Science, 43: 141-154.

DAVOUDI, S. (2003): European briefing: polycentricity in European spatial planning: from an analytical tool to a normative agenda. European Planning Studies, 11(8): 979-999.

DEMETER, G. (2020): Estimating regional inequalities in the Carpathian Basin - Historical origins and recent outcomes (1880-2010). Regional Statistics, 10(1): 23-59.

DEMETER, G., BAGDI, R. (2018): Some Methods to Quantify Migration in Hungary. In: Pejkovska, P., Demeter, G. [eds.]: Migrations of People and Ideas in Bulgaria and Hungary, $19^{\text {th }}-21^{\text {st }}$ Centuries (pp. 126-151). Sofia, Paradigma

DEMETER, G., RADICS, Z. (2009): Centrumok és perifériák a Monarchia szétesése után: az új határok racionalitásának vizsgálata gravitációs modellek alapján. Közép-Európai Közlemények, 2(2-3): 151-160.

DOORN, P. K. (1985): Geographical analysis of early modern data in ancient historical research: the example of the Strouza Region Project in central Greece. Transactions of the Institute of British Geographers, 10(3): 275-291.

ETHINGTON, P. J. (2007): Placing the past: 'Groundwork' for a spatial theory of history. Rethinking History, 11(4): 465-493.

EVANS, R. J. (2004): Language and state building: The case of the Habsburg Monarchy. Austrian History Yearbook, 35: $1-24$.

EVANS, R. J.W. (2020): Remembering the fall of the Habsburg Monarchy one hundred Years on: three master interpretations. Austrian History Yearbook, 51: 269-291.

EWEN, S. (2016): What is Urban History? Cambridge, UK, Polity Press.

FIELDS, G. (1999): Urbanization and the transition from agrarian to industrial society. Berkeley Planning Journal, 13(1): 102-128

FIK, T. J., MULLIGAN, G. F. (1990): Spatial flows and competing central places: towards a general theory of hierarchical interaction. Environment and Planning A, 22(4): 527-549.

FILET, C. (2017): An attempt to estimate the impact of the spread of economic flows on Latenian urbanization. Frontiers in Digital Humanities, 3(10).

FOTHERINGHAM，A.S. (1981): Spatial structure and distance-decay parameters. Annals of the association of American geographers, 71(3): 425-436.

FOTHERINGHAM, A.S. (1983): A new set of spatialinteraction models: the theory of competing destinations. Environment and Planning A, 15(1): 15-36.

FOTHERINGHAM, A. S. (1986): Modelling hierarchical destination choice. Environment and Planning A, 18(3): 401-418

FOTHERINGHAM, A. S., BRUNSDON, C., CHARLTON, M. (2000): Quantitative geography: perspectives on spatial data analysis. London, Sage.

FOTHERINGHAM, A. S., CHARLTON, M., BRUNSDON, C. (1996): The geography of parameter space: an investigation of spatial non-stationarity. International Journal of Geographical Information Systems, 10(5): 605-627.

FOTHERINGHAM, A. S., O’KELLY, M. E. (1989): Spatial interaction models: formulations and applications. London, Kluwer.

GORDON, I. (2010): Entropy, variety, economics, and spatial interaction. Geographical Analysis, 42(4): 446-471.

GREGORY， I. N., GEDDES，A. [eds.] (2014): Toward spatial humanities: historical GIS and spatial history. Bloomington, Indiana University Press.

GREGORY, I., DEBATS, D., LAFRENIERE, D. [eds.] (2018): The Routledge companion to spatial history. London, Routledge.

GYŐRI, R. (2000): The system of trade gravitation areas of the Hungarian Kisalföld in 1925. Tér és Társadalom, 14(2-3): 303-309.

GYÖRI， R., JANKÓ, F. (2009): Nyugat-Dunántúl és Burgenland regionális fejlettségi különbségeinek 
alakulása 1910 és 2001 között. Soproni szemle, kultúrtörténeti folyóirat. 63(2): 218-238.

HÄGERSTRAND, T. (1957): Migration and area. Survey of a sample of Swedish migration fields and hypothetical considerations on their genesis. Lund Studies in Geography B, 13: 27-158.

HAJDÚ, Z. (2020): Structural and administrative implications of the Trianon Peace Treaty, 1920. Regional Statistics, 10(1): 3-22.

HALÁS, M., KLAPKA, P. (2010): Regionalizace České republiky z hlediska modelování prostorových interakcí. Geografie, 115(2): 144-160.

HALÁS, M., KLAPKA, P. (2012): Contribution to regional division of Slovakia based on the application of the Reilly's model. Hungarian Geographical Bulletin, 61(3): 237-255.

HALÁS, M., KLAPKA, P. (2015): Spatial influence of regional centres of Slovakia: analysis based on the distance-decay function. Rendiconti Lincei - Scienze Fisiche e Naturali, 26(2): 169-185.

HALL, P. G., PAIN, K. [eds.] (2006): The polycentric metropolis: learning from mega-city regions in Europe. London, Earthscan.

HU, P., POOLER, J. (2002): An empirical test of the competing destinations model. Journal of Geographical Systems, 4(3): 301-323.

HUFF, D. L. (1963): A probabilistic analysis of shopping center trade areas. Land Economics, 39(1): 81-90.

HUFF, D. L. (1964): Defining and estimating a trading area. Journal of Marketing, 28(3): 34-38.

IANOŞ, I. (1987): Oraşele şi organizarea spaţiului geografic (Studiu de geografie economică supra territoriului României). Bucureşti, Editura Academiei Republicii Socialiste România.

JAKLE, J. A. (1971): Time, space, and the geographic past: a prospectus for historical geography. The American Historical Review, 76(4): 1084-1103.

JUDSON, P.M. (2016): The Habsburg Empire: a new history. Cambridge, MA, The Belknap Press of Harvard University Press.

JUDSON, P. M. (2017): "Where our commonality is necessary...": rethinking the end of the Habsburg Monarchy. Austrian History Yearbook, 48: 1-21.

JUNG, A. F. (1959): Is Reilly's law of retail gravitation always true? Journal of Marketing, 24(2): 62-63.

KANN, R.A. (1974): A history of the Habsburg Empire, 1526-1918. Berkeley, University of California Press.

KENNY, N., MADGIN, R. [eds.] (2015): Cities beyond borders: comparative and transnational approaches to Urban History. Farnham, Ashgate Publishing.

KINGSTON, R. (2010): Mind over matter? History and the spatial turn. Cultural and Social History, 7(1): 111-121.

KLAPKA, P., HALÁS, M. (2016): Conceptualising patterns of spatial flows: Five decades of advances in the definition and use of functional regions. Moravian Geographical Reports, 24(2): 2-11.

KLAPKA, P., NIEDŹWIEDŹOVÁ, K. (2010): Geographical organisation of the Nový Jičín region: transformations of its selected aspects during the Industrial Revolution
(Czech lands). Moravian Geographical Reports, 18(4): 39-55.

KLAUTKE, E. (2010): Urban history and modernity in Central Europe. The Historical Journal, 53(1): 177-195.

KOCSIS, K., TÁTRAI, P. (2021): Ethnicity, language. In: Kocsis, K. [ed.]: National Atlas of Hungary - Society (pp. 70-77). Budapest, CSFK Geographical Institute.

KOŻUCHOWSKI, A. (2013): The afterlife of Austria-Hungary: the image of the Habsburg Monarchy in interwar Europe. Pittsburg, University of Pittsburgh Press.

KRAUSMANN, F. (2013): A city and its hinterland: Vienna's energy metabolism 1800-2006. In: Singh, S. et al. [eds.]: Long term socio-ecological research: studies in societynature interactions across spatial and temporal scales (pp. 247-268). New York, Springer.

LEE, M. L., PACE, R. K. (2005): Spatial distribution of retail sales. The Journal of Real Estate Finance and Economics, 31(1): 53-69.

LEE, R. (2005): Configuring the region: maritime trade and port-hinterland relations in Bremen, 1815-1914. Urban History, 32(2): 247-287.

MAKAŠ, E. G., CONLEY, T. D. [eds.] (2009): Capital cities in the aftermath of empires: planning in Central and Southeastern Europe. London, Routledge.

MILLER, P., MORELON, C. [eds.] (2018): Embers of empire: continuity and rupture in the Habsburg successor states after 1918. New York, Berghahn Books.

MOHL, R. A. (1998): City and region: the missing dimension in US urban history. Journal of Urban History, 25(1): 3-21.

MOOS, C. (2016): Habsburg post mortem: Betrachtungen zum Weiterleben der Habsburgermonarchie. Wien, Böhlau Verlag.

OPENSHAW, S., VENERIS, Y. (2003): Numerical experiments with central place theory and spatial interaction modelling. Environment and Planning A, 35(8): 1389-1403.

PAPP, I., PÉNZES, J. (2017): Development paths of settlements in the border area of Szabolcs-Szatmár-Bereg county, Hungary. In: Tुoca, C. V. etal. [eds.]: Achievements, Contemporary Approaches and Perspectives in the Evaluation of Crossborder Cooperation (pp. 15-23). Debrecen.

PARR, J. B. (1997): The law of retail gravitation: insights from another law. Environment and Planning A, 29(8): 1477-1492.

PÉNZES, J. (2020): The impact of the Trianon Peace Treaty on the border zones-an attempt to analyse the historic territorial development pattern and its changes in Hungary. Regional Statistics, 10(1): 60-81.

PLANE, D. A. (1982): An information theoretic approach to the estimation of migration flows. Journal of Regional Science, 22(4): 441-456.

POOLER, J. (1994): An extended family of spatial interaction models. Progress in Human Geography, 18(1): 17-39.

RAE, D. W. (2003): City: urbanism and its end. New HavenLondon, Yale University Press.

RANKIN, W. (2020): How the visual is spatial: Contemporary spatial history, neo-marxism, and the ghost of Braudel. History and Theory, 59(3): 311-342. 
RAVENSTEIN, E. G. (1885): The laws of migration. Journal of Royal Statistical Society, 48: 167-235.

ŘEHÁK, S., HALÁS, M., KLAPKA, P. (2009): Několik poznámek $\mathrm{k}$ možnostem aplikace Reillyho modelu. Geographia Moravica, 1: 47-58.

REILLY, W. J. (1929): Methods for the study of retail relationships. In: University of Texas Bulletin no. 2944. Austin, University of Texas.

REILLY, W. J. (1931): The law of retail gravitation. New York, Knickerbocker Press.

RIHLL, T. E., WILSON, A. G. (1987): Spatial interaction and structural models in historical analysis: some possibilities and an example. Histoire \& Mesure, 2(1): 5-32.

RODGER, R. (1992): Urban history: prospect and retrospect. Urban History, 19(1): 1-22.

ROY, J. R., THILL, J. C. (2004): Spatial interaction modelling Papers in Regional Science, 83(1): 339-361.

ROZENBLAT C., PUMAIN, D. (2018): Metropolization and polycentrism in the European urban system. In: Rozenblat, C. [ed.]: International and Transnational Perspectives on Urban Systems (pp. 117-141). Singapore, Springer.

RUMPLER, H., URBANITSCH, P. [eds.] (2010): Die Habsburgermonarchie 1848-1918. Band IX: Soziale Strukturen. Teilband 1: Von der feudal-agrarischen zur bürgerlich-industriellen Gesellschaft. Teilband 2: Die Gesellschaft der Habsburgermonarchie im Kartenbild. Wien, Verlag der Österreichischen Akademie der Wissenschaften.

SEN, A., SMITH, T. E. (1995): Gravity models of spatial interaction behavior. Berlin-Heidelberg, Springer Verlag.

SENIOR, M. L. (1979): From gravity modelling to entropy maximising: a pedagogic guide. Progress in Human Geography, 3(2): 174-210.

SHEPPARD, E. S. (1978): Theoretical underpinnings of the gravity hypothesis. Geographical Analysis, 10(4): 386-402.

SKED, A. (2013): The decline and fall of the Habsburg Empire, 1815-1918. Oxon, Routledge.

SNICKARS, F., WEIBULL, J.W. (1977): A minimum information principle. Regional Science and Urban Economics, 7(1-2): 137-168.

STEWART, J. Q. (1948): Demographic gravitation: evidence and applications. Sociometry, 11(1/2): 31-58.
STIMPSON, R. J., STOUGH, R. R., ROBERTS, B. H. (2006): Regional Economic Development. Berlin, Springer.

SÜLI-ZAKAR, I. (1992): A study of state borders as factors blocking socio-economic progress in North-Eastern Hungary. Földrajzi Közlemények International Edition, 40: 53-63.

SZILÁGYI, F., ELEKES, T. (2020): Changes in administration, spatial structure, and demography in the Partium region since the Treaty of Trianon. Regional Statistics, 10(1): 101-119.

SZILÁGYI, Z. (2017): Visualising Areas Lacking Cities a Possible Application of the Geographic Information System (GIS) and the Gravity Model in History, Based on the Example of the Great Hungarian Plain of Trianon (1910-1930). Új Nézöpont, 4(2): 31-69.

TAYLOR, A. J. P. (1976): The Habsburg monarchy, 1809 1918: a history of the Austrian Empire and AustriaHungary. Chicago, University of Chicago Press.

THOMPSON, D. L. (1966): Future directions in retail area research. Economic Geography, 42(1): 1-18.

WHEATLEY, N. (2019): Central Europe as Ground Zero of the New International Order. Slavic Review, 78(4): 900-911.

WILSON, A. (2010): Entropy in urban and regional modelling: retrospect and prospect. Geographical Analysis, 42(4): 364-394.

WILSON, A. (2012): Geographical modelling for archaeology and history: Two case studies. Advances in Complex Systems, 15(1-2): 1150008 .

WILSON, A. (2018): The future of urban modelling. Applied Spatial Analysis and Policy, 11(4): 647-655.

WILSON, A. G. (1967): Statistical theory of spatial distribution models. Transportation Research, 1: 253-269.

WILSON, A. G. (1970): Entropy in urban and regional modelling. London, Pion.

WILSON, A. G. (1971): A family of spatial interaction models, and associated developments. Environment and Planning, 3(1): 1-32.

WILSON, A. G. (1974): Urban and regional models in geography and planning. London, Wiley.

ZIPF, G. K. (1949): Human behavior and the principle of least effort. An introduction to human ecology. Cambridge, MA, Addison-Wesley.

\section{Please cite this article as:}

KLAPKA, P., ERLEBACH, M. (2021): The contribution of spatial interaction modelling to spatial history: The case of central places and their hinterlands in the territory of the Austro-Hungarian Empire. Moravian Geographical Reports, 29(4): 267-277. doi: https://doi. org/10.2478/mgr-2021-0019 